\title{
NON-TRADITIONAL NON-DESTRUCTIVE TESTING OF THE ALKALI-ACTIVATED SLAG MORTAR DURING THE HARDENING
}

\author{
NETRADICIONALNO NEPORUŠNO PREIZKUŠANJE Z \\ ALKALIJAMI AKTIVIRANE MALTE MED STRJEVANJEM
}

\author{
Libor Topoláŕ, Peter Rypák, Kristýna Timčaková-Šamárková, Luboš Pazdera, \\ Pavel Rovnaník \\ Brno University of Technology, Faculty of Civil Engineering, Veveri 331/95, 60200 Brno, Czech Republic \\ topolar.1@fce.vutbr.cz \\ Prejem rokopisa - received: 2014-07-30; sprejem za objavo - accepted for publication: 2015-01-30
}

doi:10.17222/mit.2014.130

\begin{abstract}
This paper reports the results of the measurements of alkali-activated slag mortars made during the hardening and drying of specimens. The alkali-activated slag is a material with a great potential for practical use. The main drawback of this material is its high level of autogenous and, especially, drying shrinkage, which causes a deterioration in the mechanical properties. The aim of this paper is to present the effects of the treatment method for mortars and the curing time on the microstructures of the alkali-activated slag mortars. The knowledge of the microstructure/performance relationship is the key to a true understanding of the material behaviour. The results obtained in the laboratory are useful for understanding the various stages of the micro-cracking activity during the hardening process in quasi-brittle materials such as alkali-activated slag mortars and for their extension to field applications. Non-destructive acoustic-analysis methods - the impact-echo method as a traditional method and the acoustic-emission method as a non-traditional method for civil engineering - were used for the experiment. The principle of the impact-echo method is based on analysing the response of an elastic-impulse-induced mechanical wave. Acoustic emission is the term for the noise emitted by materials and structures when they are subjected to stress. The types of stress can be mechanical, thermal or chemical. Ultrasound testing and the loss in mass were used as complementary methods for the tested samples.
\end{abstract}

Keywords: acoustic-emission method, loss in mass, impact-echo method, ultrasound testing, alkali-activated slag mortars

Članek obravnava rezultate meritev med strjevanjem in sušenjem vzorcev malt, aktiviranih z alkalijami. Z alkalijami aktivirana žlindra je material, ki ima velik potencial za praktično uporabo. Glavna pomanjkljivost tega materiala je, da ima sam po sebi, še posebno pa pri sušenju, velik skrček, ki povzroči poslabšanje mehanskih lastnosti. Namen tega članka je predstavitev vpliva metode obdelave malte in časa strjevanja na mikrostrukturo z alkalijami aktivirane malte. Razumevanje odvisnosti med mikrostrukturo in zmogljivostjo je ključ za pravilno razumevanje vedenja materiala. Rezultati, dobljeni v laboratoriju, so koristni za razumevanje različnih stopenj nastajanja mikrorazpok med procesom strjevanja kvazikrhkega materiala, kot je malta $\mathrm{z}$ žlindro, aktivirano $\mathrm{z}$ alkalijami, in za njihov prenos na gradbišče. Neporušne analizne metode $\mathrm{z}$ akustično emisijo in metoda udarec - odmev kot tradicionalne ter metoda akustične emisije kot netradicionalna metoda v gradbeništvu, so bile uporabljene pri preizkusu. Princip metode udarec - odmev temelji na analizi odgovora elastičnega impulznega mehanskega vala. Akustična emisija je izraz za hrup, ki ga oddajata material in zgradba, ko sta izpostavljena napetosti. Napetosti so lahko mehanske, termične ali kemijske. Preiskava z ultrazvokom in izguba mase sta bili uporabljeni kot komplementarni metodi pri preizkusnih vzorcih.

Ključne besede: metoda akustične emisije, izguba mase, metoda udarec - odmev, preiskava z ultrazvokom, malta z žlindro, aktivirano z alkalijami

\section{INTRODUCTION}

Alkali-activated aluminosilicate materials represent an alternative to ordinary Portland-cement-based materials, reducing the impact of the building industry on the environment and exhibiting new superior properties. Alkali-activated slag (AAS) is based on granulated blast-furnace slag that can be activated by alkali hydroxides, carbonates or, most preferably, by silicates. ${ }^{1}$ The type and dosage of the activator as well as the way of the curing have significant effects on the hydration course and final mechanical properties. ${ }^{2}$ The major disadvantage of AAS is an increased shrinkage during the hardening period, caused by both the autogenous and drying shrinkage, which finally results in a volume contraction, micro-cracking and deterioration of tensile and bending properties. ${ }^{3}$
The impact-echo method (IE) is a type of the nondestructive testing method. A short-term mechanical impact, generated by tapping a hammer against the surface of a concrete structure, produces low-frequency stress waves which propagate into the structure. ${ }^{4}$ A wave generated in this way propagates through the specimen structure and reflects from the defects located in the volume of specimen or on its surface. Surface displacements caused by the reflected waves are recorded by a transducer located adjacent to the impact. ${ }^{5}$ The signal is digitized via an analogue/digital data system and transmitted to a computer's memory. This signal describes the transient local vibrations, caused by the mechanicalwave multiple reflections inside the structure. The dominant frequencies of these vibrations give an account of the condition of the structure that the waves pass through. ${ }^{6}$ 
Acoustic emission (AE) is the term for the noise emitted by materials and structures when they are subjected to stress. The types of stresses can be mechanical, thermal or chemical. This emission is caused by a rapid release of the energy within a material due to the events such as a crack formation and its subsequent extension occurring under the applied stress, generating transient elastic waves that can be detected by piezoelectric sensors. The acoustic-emission system allows us to monitor the changes in the material behaviour over a long time and without moving one of its components, i.e., sensors. This makes the technique quite unique along with the ability to detect the crack propagation occurring not only on the surface but also deep inside the material. The acoustic-emission method is considered to be a "passive" non-destructive technique, because it usually identifies defects while they develop during the test. ${ }^{7}$

Ultrasonic testing is the name given to the study and application of ultrasound, which is a sound too high to be detected by the human ear, i.e., of the frequencies greater than about $18 \mathrm{kHz}$. Ultrasonic waves have a wide variety of applications. For example, ultrasound with high intensity is used for cutting, cleaning and destroying a tissue in medicine. For the non-destructive testing (NDT), ultrasound with a lower intensity is used. An ultrasonic inspection can be used for a flaw detection/ evaluation, dimensional measurements, a material characterization and more. Ultrasonic testing (UT) is based on the propagation of low-amplitude waves through a material, measuring the time of travel or detecting any change in the intensity over a given distance. Applications include distance gauging, flaw detection and parameter measurement (such as the elastic modulus and the grain size), all relating to the material structure. ${ }^{8}$

\section{EXPERIMENTAL PART}

\subsection{Material}

The mixture consisted of $450 \mathrm{~g}$ of fine-grained granulated blast-furnace slag Štramberk 380 (a specific

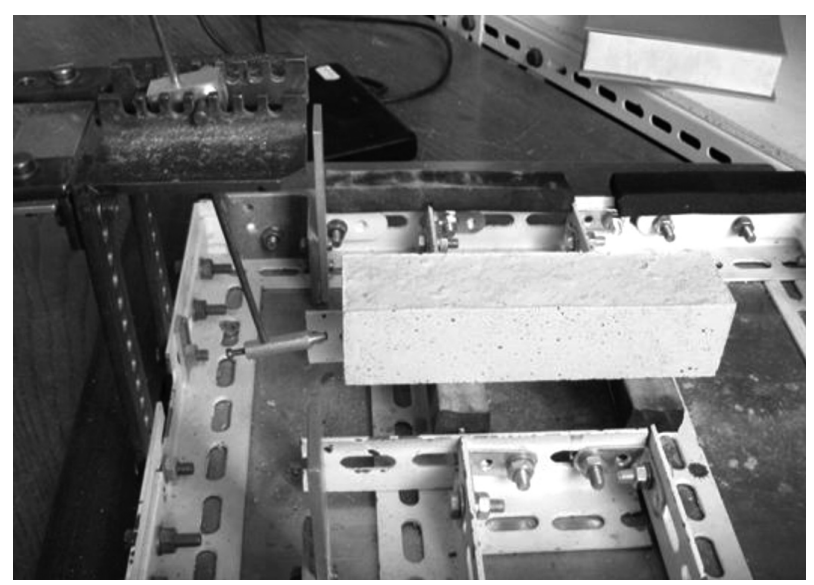

Figure 1: Photography of the impact-echo measurement Slika 1: Posnetek meritve udarec - odmev surface area of $380 \mathrm{~m}^{2} \mathrm{~kg}^{-1}$ ), $180 \mathrm{~g}$ of sodium silicate (water glass) with a modulus of 1.6, $1350 \mathrm{~g}$ of silica sand and $95 \mathrm{~mL}$ of water. The AAS slurry was poured into steel moulds $(40 \mathrm{~mm} \times 40 \mathrm{~mm} \times 160 \mathrm{~mm})$ to set and after $24 \mathrm{~h}$ the samples were demoulded and immersed in water for another (2, 6 and 27) d before the testing.

\subsection{Experimental set-up}

For the impact-echo method, a short mechanical impulse (a hammer blow) was applied to the surface of a specimen during the test and detected by means of a piezoelectric sensor (Figure 1). The impulse reflected from the surface and also from the micro-cracks and defects present on the specimen under investigation. The resonance frequency created in this way was determined by means of a frequency analysis. Dominant frequencies could be determined from the response signal by means of the fast Fourier transform. A MIDI piezoelectric sensor was used to pick up the response and the respective impulses were directed into the input of a TiePie engineering oscilloscope, two-channel Handyscope HS3 with a resolution of 16 bits.

The initiation of cracks during the hardening was monitored with the method of acoustic emission. AE signals were detected by measuring equipment DAKEL XEDO with four channels (Figure 2). The AE sensors (type IDK09) were attached to the surface with beeswax.

The change in the mass during the hardening was measured using equipment QuantumX with a Z6 bending-beam load cell for the maximum mass of $50 \mathrm{~kg}$ by HBM.

Measuring equipment PUNDIT (portable ultrasonic non-destructive digital indicating tester) Plus was used for the ultrasonic testing. For the testing speed of the sound through the mortar specimens, the coefficient of variation for the repeated measurements at the same location was $2 \%$. The accuracy of the pulse velocity was

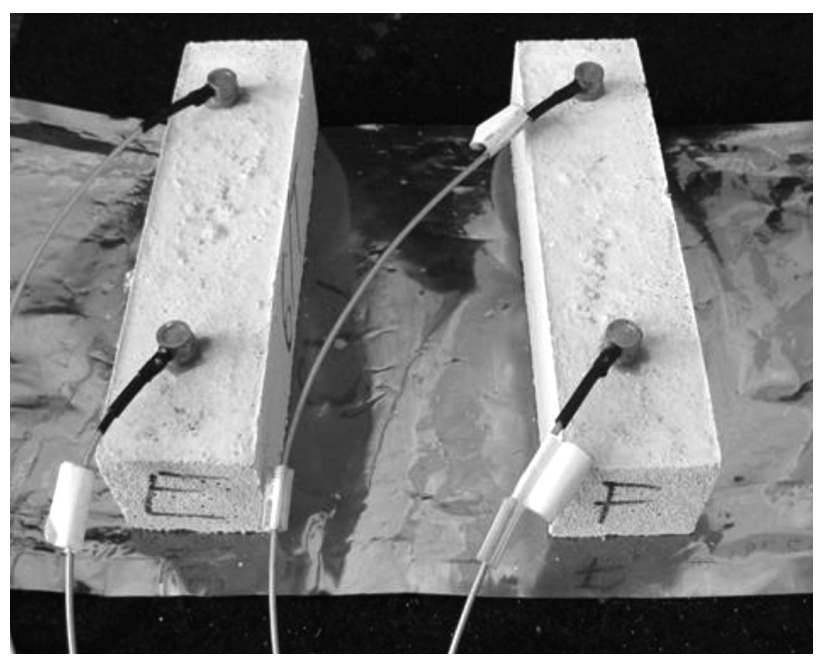

Figure 2: Photography of the acoustic-emission measurement Slika 2: Posnetek meritve akustične emisije 
a direct function of the accuracy of the measured distance between the transducer faces. The PUNDIT instruments have a transit time resolution of $0.1 \mathrm{~s}$. All the measurements were carried out for $336 \mathrm{~h}(14 \mathrm{~d})$ immediately after the specimens were pulled out of the immersion water.

\section{RESULTS AND DISCUSSION}

To evaluate the crack formation during spontaneous drying, we focused on the activity of AE with respect to the most used parameter, which is the number of signals overshooting the pre-set threshold. The diagrams in Figures 3 to $\mathbf{5}$ show the dependence of the number of overshoots and the loss of mass versus the time of measurement. It was assumed that the number of microcracks could be inferred from the AE activity. Unfortunately, the AE signals originate not only from the crack formation but also from the process of water evaporation. However, most of the AE activity was observed within the first $24 \mathrm{~h}$ of spontaneous drying, which corresponds to approximately $50 \%$ loss in mass. Therefore, at the beginning the AE signals could be attributed to both the drying process and the crack formation, whereas after 24 $\mathrm{h}$ of drying the observed signals corresponded mainly to the formation of microcracks. The highest number of overshoots during the remaining time of the measure-

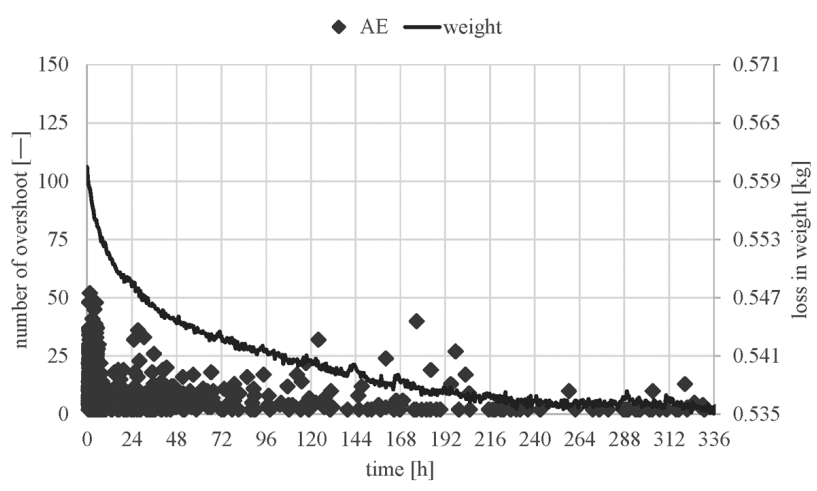

Figure 3: Results for the specimen cured in water for $2 \mathrm{~d}$

Slika 3: Rezultati vzorca, ki se je 2 d utrjeval v vodi

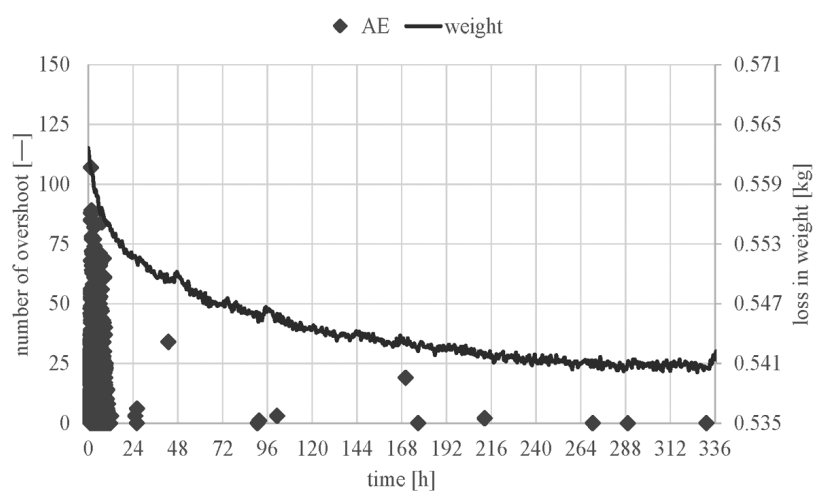

Figure 4: Results for the specimen cured in water for $6 \mathrm{~d}$ Slika 4: Rezultati vzorca, ki se je 6 d utrjeval v vodi

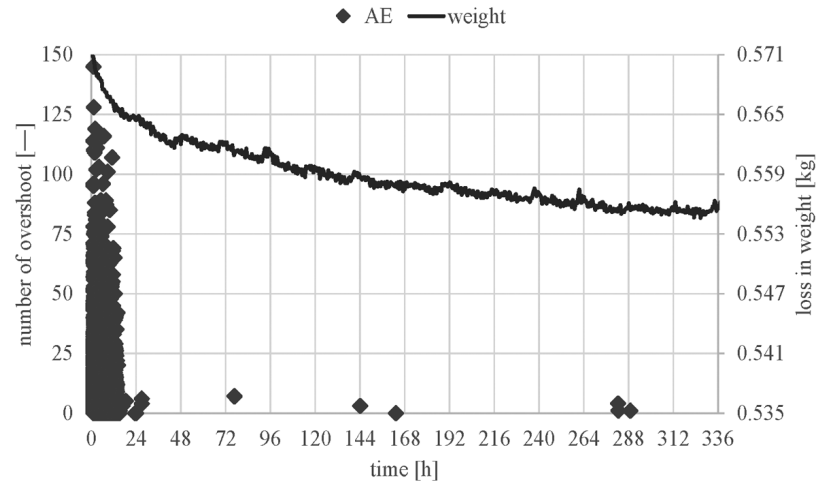

Figure 5: Results for the specimen cured in water for $27 \mathrm{~d}$

Slika 5: Rezultati vzorca, ki se je 27 d utrjeval v vodi

ment was detected for the specimen that was cured in water for $2 \mathrm{~d}$ (Figure 3). The reason for such a difference in comparison with the specimens cured for $6 \mathrm{~d}$ and $27 \mathrm{~d}$ arise from a shorter hydration time. Three days after the mixing, the hydration process was still not complete and the weak basic structure was not able to bear a heavy stress; therefore, the AAS matrix was more susceptible to the cracking caused by drying shrinkage.

To evaluate the signals with the impact-echo method the fast Fourier transform was used. The modification of the dominant frequency during the drying process is displayed in Figure 6. The results show that the frequencies decreased from the initial values of $10.10 \mathrm{kHz}, 10.86$ $\mathrm{kHz}, 12.12 \mathrm{kHz}$ to the steady values of $5.90 \mathrm{kHz}, 7.50$ $\mathrm{kHz}, 8.44 \mathrm{kHz}$, respectively, for the specimens cured in water for (2, 6 and 27) d, respectively. Similarly, the ultrasonic velocity decreased from the initial values of $(3760,3960,4450) \mathrm{m} \mathrm{s}^{-1}$ to the steady values of $(2010$, $2470,2970) \mathrm{m} \mathrm{s}^{-1}$, respectively, for the specimens immersed in water for (2, 6 and 27) d, respectively (Figure 7). The pulse cannot travel across the material/air interface, but it is able to travel from the transmitter to the receiver by diffraction at the crack edge. As the travel path is longer than the distance between the transducers, the apparent pulse velocity is lower than through the sound material.

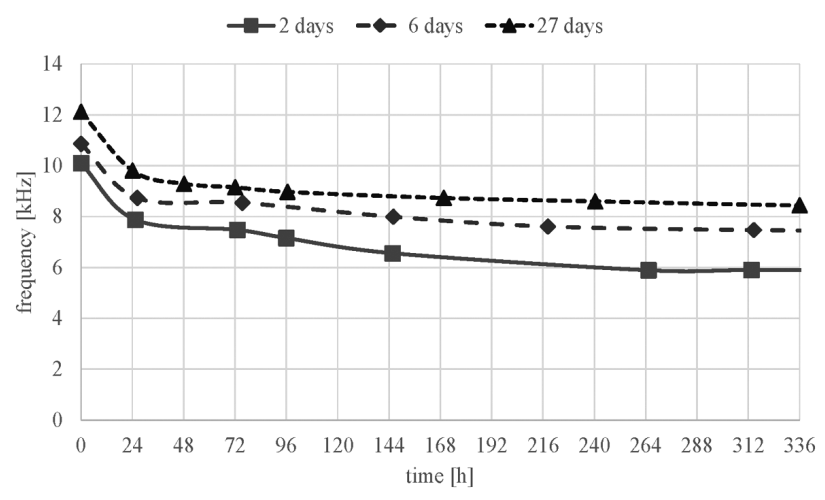

Figure 6: Change in the dominant frequency over time Slika 6: Spreminjanje prevladujoče frekvence s časom 


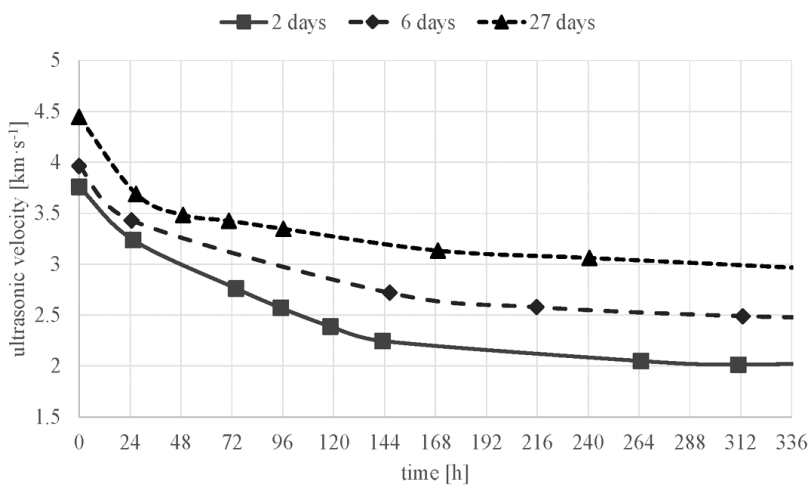

Figure 7: Change in the ultrasonic velocity over time Slika 7: Spreminjanje hitrosti ultrazvoka s časom

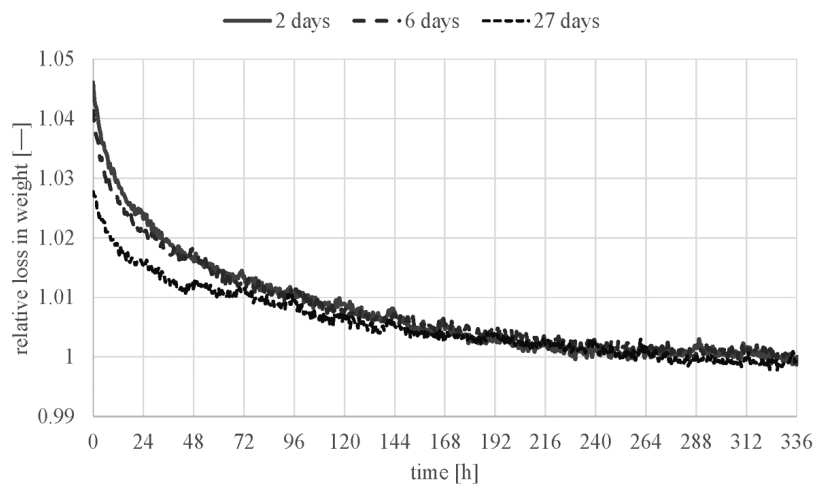

Figure 8: Change in the loss in mass in relative units over time Slika 8: Spreminjanje izgube mase v relativnih enotah s časom

The frequencies as well as the ultrasonic velocity exhibit a decreasing trend of the values. The initial, quite steep drop corresponds to the evaporation of the water absorbed in the pore system, leaving air voids that do not transmit ultrasonic signals. The further decrease connected with the crack formation caused by drying shrinkage is bit more moderate. These results are in very good accordance with the acoustic-emission measurements. Higher absolute values of the ultrasonic velocity for the specimens cured for longer times are associated with a denser and more compact structure.

The comparison in the mass loss for variously cured specimens is given in Figure 8. The loss in mass was calculated relative to the steady state after spontaneous drying. The relative mass of the steady state was set to 1 . The specimens cured for $27 \mathrm{~d}$ in water lost only $28 \%$ of mass, whereas the specimens immersed in the water bath for $6 \mathrm{~d}$ and $2 \mathrm{~d}$ decreased their mass by $41 \%$ and $46 \%$, respectively. It can be assumed that the AAS specimens that were not completely hydrated were more porous and, hence, contained higher amounts of the evaporable water.

\section{CONCLUSIONS}

The paper deals with the use acoustic non-destructive methods for monitoring the alkali-activated slag mortars during the process of drying and hardening. Volume variations in the alkali-activated slag mortars are connected with autogenous and drying shrinkage. The loss in mass observed during the setting and hardening of AAS is a result of the drying process. The rate of the moisture release is in good accordance with the number of signals detected with the AE method. The changes in the dominant frequency towards lower values detected with the impact-echo method for all three specimens are visible and there is also a trend of a decrease in the ultrasonic velocity, indicating that a large number of new inhomogeneities appeared in the tested specimens during their storage in air. It is assumed that most of these changes can be attributed to the crack formation; therefore, it can be concluded that the main process leading to a deterioration of the AAS binder is the drying shrinkage.

\section{Acknowledgement}

This paper was elaborated with the financial support of the Czech Science Foundation project CSF No. 13-09518S and the Ministry of Education, Youth and Sports of the Czech Republic under the "National Sustainability Programme I" (project No. LO1408 AdMaS UP), as an activity of the regional Centre AdMaS (Advanced Materials, Structures and Technologies).

\section{REFERENCES}

${ }^{1}$ C. Shi, P. V. Krivenko, D. Roy, Alkali-Activated Cements and Concretes, Taylor \& Francis, Oxon, UK 2006, doi:10.4324/ 9780203390672

${ }^{2}$ C. Shi, R. L. Day, Some factors affecting early hydration characteristics of alkali-slag cements, Cem. Concr. Res., 26 (1996), 439-447, doi:10.1016/S0008-8846(96)85031-9

${ }^{3}$ M. A. Cincotto, A. A. Melo, E. L. Repetto, Effect of different activators type and dosages and relation with autogenous shrinkage of activated blast furnace slag cement, Proceedings of the 11th International Congress on the Chemistry of Cement, Durban, South Africa, 2003, 1878-1888

${ }^{4}$ M. Sansalone, N. J. Carino, Impact-Echo: A Method for Flaw Detection in Concrete Using Transient Stress Waves, National Bureau of Standards, Gaithersburg, Maryland, 1986, NBSIR 86-3452

${ }^{5}$ I. Plšková, Z. Chobola, M. Matysík, Assessment of ceramic tile frost resistance by means of the frequency inspection method, Ceramics-Silikáty, 55 (2011) 2, 176-182

${ }^{6}$ M. T. Liang, P. J. Su, Detection of Corrosion Damage of Rebar in Concrete Using Impact-Echo Method, Cem. Concr. Res., 31 (2001), 1427-1436, doi:10.1016/S0008-8846(01)00569-5

${ }^{7}$ Ch. U. Grosse, M. Ohtsu, Acoustic Emission Testing, Springer-Verlag, Berlin 2008, doi:10.1007/978-3-540-69972-9

${ }^{8}$ J. Blitz, G. Simpson, Ultrasonic Methods of Non-Destructive Testing, Springer-Verlag, New York, LLC 1991 